\title{
Comunicação pública na prevenção da evasão: a experiência de um aplicativo sobre Ensino Médio Integrado
}

Public communication on dropout school prevention: the experience of an application on Integrated High School

Comunicación pública en la prevención del abandono escolar: la experiencia de una aplicación en Integrated High School

ELISA CARMo Franco Almeida (iD) a

PAULA REIS DE MIRANDA (iD ${ }^{\mathrm{b}}$

\section{Resumo}

A principal causa de evasão escolar no Ensino Médio Integrado (EMI) do IF Sudeste MG - Campus Rio Pomba é a falta de conhecimento sobre a identidade dos cursos integrados, que sujeita os estudantes a surpresas pós-ingresso. Considerando-se tal distanciamento entre a instituição e o público-alvo da Educação Profissional e Tecnológica, o presente estudo buscou validar a hipótese de que um aplicativo para dispositivos móveis, voltado a aproximar estudantes adolescentes, constituiria um potencial aliado do Campus Rio Pomba na prevenção da evasão escolar. Tal hipótese relaciona-se ao comprometimento com a trajetória acadêmica, a instituição e a carreira, compreendido como um fator de permanência. Assim, realizou-se um estudo de caso voltado ao curso integrado com maior índice de evasão do Campus Rio Pomba: o de Agropecuária. Revisão bibliográfica, estudo de experiências educacionais recentes, com tecnologia e

a IF Sudeste MG, Rio Pomba, MG, Brasil. Mestre em Educação Profissional e Tecnológica, e-mail: elisa.franco@ifsudestemg.edu.br

b IF Sudeste MG, Rio Pomba, MG, Brasil. Doutora em Educação, e-mail: paula.reis@ifsudestemg.edu.br 
análise de resultados de entrevistas com estudantes externos ao IF Sudeste MG compuseram o estudo e embasaram a criação de um protótipo de aplicativo em formato interativo, contendo informações curriculares, imagens, vídeos e outros recursos voltados ao curso em questão. O protótipo foi testado pelos mesmos sujeitos adolescentes entrevistados, e seus relatos em questionários apontam que a tecnologia foi capaz de ampliar o conhecimento sobre o IF Sudeste MG e o curso de Agropecuária na modalidade integrada, além de modificar perspectivas de futuro. Validou-se, portanto, a hipótese inicial: o aplicativo proposto apresenta potencial de prevenção da evasão, ao combater a principal origem do problema - o desconhecimento.

Palavras-chave: Educação Profissional e Tecnológica. Tecnologia. Adolescentes. Inovação.

\section{Abstract}

The main cause of school dropout in the IF Sudeste MG - Rio Pomba Campus' Integrated High School is the lack of knowledge about the identity of the integrated courses, which subjects students to post-admission surprises. Considering this distance between the institution and the target audience of Professional and Technological Education (PTE), the present study sought to validate the hypothesis that a mobile application aimed at approaching adolescent students would be a potential ally of the Rio Pomba Campus in the prevention of school dropouts. This hypothesis is related to the commitment to the academic trajectory, the institution and the career - pointed as a permanence factor. Thus, a case study focused on the integrated course with the highest dropout rate of the Rio Pomba Campus was carried out: that of Agropecuaria. Bibliographic review, study of recent educational experiences with technology and analysis of results of interviews with students outside the IF Sudeste MG composed the study and supported the creation of an interactive prototype application containing curricular information, images, videos and other resources about the course in question. The prototype was tested by the same adolescent subjects interviewed and their reports in questionnaires indicate that the technology was able to increase the knowledge about the Rio Pomba Campus and the Agropecuaria course in the integrated modality, besides modifying future perspectives. Therefore, the initial hypothesis was validated: the proposed application has the potential to prevent evasion by combating the main source of the problem - lack of knowledge.

Keywords: Professional and Technological Education. Technology. Adolescents. Innovation.

\section{Resumen}

La principal causa de evasión escolar en la Escuela Secundaria Integrada (ESI) del IF Sudeste MG - Campus Rio Pomba es la falta de conocimiento sobre la identidad de los cursos integrados, que sujeta a los estudiantes a sorpresas post-ingreso. En el presente estudio se buscó validar la hipótesis de que una aplicación para dispositivos móviles 
orientada a acercar a estudiantes adolescentes constituiría un potencial aliado del Campus Rio Pomba en la prevención de la evasión escolar. Tal hipótesis se relaciona con el compromiso con la trayectoria académica, la institución y la carrera, comprendido como un factor de permanencia. Así, se realizó un estudio de caso orientado al curso integrado con mayor índice de evasión del Campus Rio Pomba: el de Agropecuaria. La revisión bibliográfica, estudio de experiencias educativas recientes con tecnología y análisis de resultados de entrevistas con estudiantes externos al IF Sudeste MG compuso el estudio y basó la creación de un prototipo de aplicación en formato interactivo, conteniendo informaciones curriculares, imágenes, videos y otros recursos sobre el curso en cuestión. El prototipo fue probado por los mismos sujetos adolescentes entrevistados y sus relatos en cuestionarios apuntan que la tecnología fue capaz de ampliar el conocimiento sobre el IF Sudeste MG y el curso de Agropecuaria en la modalidad integrada, además de modificar perspectivas de futuro. Se validó, por lo tanto, la hipótesis inicial: la aplicación propuesto presenta potencial de prevención de la evasión, al combatir el principal origen del problema (el desconocimiento).

Palabras clave: Educación Profesional y Tecnológica. Tecnología. Adolescentes. Innovación.

\section{Introdução}

A compreensão da evasão escolar perpassa um "vasto e intricado conjunto de circunstâncias individuais, institucionais e sociais" (DORE \& LUSCHER, 2011, p. 777). A evasão é um processo complexo, dinâmico e cumulativo de desengajamento do estudante da vida da escola.

Sabe-se também que ela afeta especialmente as classes populares, cujas chances de evadir-se são maiores se comparadas às de níveis socioeconômicos mais altos (TINTO, 1975). E este é um agravante a ser necessariamente levado em conta pelos Institutos Federais de Educação Profissional e Tecnológica (IFs), dada a função social destas entidades. Tal função está expressa em suas Diretrizes e Concepções (MEC, 2010) e, especificamente do Plano de Desenvolvimento Institucional do Instituto Federal do Sudeste de Minas Gerais, traduzida como um "claro compromisso institucional de empreender esforços para minimizar os efeitos das desigualdades sociais e regionais” (IF SUDESTE MG, 2014, p. 307).

Pela natureza dos IFs (BRASIL, 2008), o Ensino Médio Integrado é uma modalidade de ensino prioritária e as taxas de evasão nesta forma de oferta costumam ser menores que nas demais modalidades por eles ofertadas: 9,7\% era a 
média nacional registrada por estas instituições até o final do ano de 2018 (MEC, 2019). Todavia, de acordo com a Plataforma Nilo Peçanha, no IF Sudeste MG Campus Rio Pomba, o índice médio de evasão entre os cinco cursos ofertados na referida modalidade era de $12,3 \%$, até o fim do ano de 2018 , sendo índice mais alto apresentado pelo Técnico em Agropecuária: 20,9\%.

Tal cenário sofre influência de diversos fatores, entre estes a falta de conhecimento dos ingressantes quanto à identidade dos cursos ofertados. Segundo o próprio IF Sudeste MG (2016), os alunos frequentemente relatam, antes de evadir, que "esperavam outro tipo de curso" (p. 189), levando a crer que o conhecimento destes mesmos alunos, no momento anterior ao ingresso na instituição, é inexistente ou não corresponde à identidade do EMI e do próprio Campus Rio Pomba.

Com base na expectativa relatada por outro tipo de curso, entende-se que evasão no EMI do IF Sudeste MG é um problema que passa pela comunicação. Faltam informação e conhecimento, lacuna capaz de comprometer o futuro dos adolescentes. E, assim, o problema passa especialmente pela comunicação pública. Compreendida aqui como aquela que busca "informar para a construção da cidadania” (BRANDÃO, 2009, p. 6), a comunicação pública relaciona-se à democracia e à prevalência do interesse público, apresentando potencial de promover conhecimento sobre a identidade dos cursos sem ignorar as necessidades e os interesses dos adolescentes a quem o EMI se destina.

Nesse sentido, este estudo buscou não apenas compreender a referida falta de conhecimento como causa de evasão escolar, mas validar a hipótese de que um aplicativo para dispositivos móveis, voltado a estudantes adolescentes, constituiria um potencial aliado do Campus Rio Pomba na prevenção de desligamentos, à medida em que favorecesse a promoção de conhecimento de identidades - do curso e da instituição como um todo — favorecendo, portando, o engajamento à proposta de formação em questão.

Primeiramente, faz-se necessário compreender a relação entre falta de conhecimento de identidades, comunicação pública, adolescência e tecnologias de comunicação modernas utilizadas por adolescentes, identificando de que maneira um aplicativo revela-se aliado à permanência dos alunos no EMI, de acordo com a 
identidade deste público e de acordo com experiências educacionais já realizadas. Portanto, uma revisão bibliográfica dá início a este estudo.

$\mathrm{Na}$ fase empírica, foram analisados resultados de entrevistas coletivas com adolescentes externos ao IF Sudeste MG, na busca de traçar uma proposta de aplicativo coerente com as particularidades deste contexto. Por fim, é apresentado o protótipo de aplicativo resultante da pesquisa, bem como os resultados da validação desta ferramenta tecnológica, que veio a ser utilizada e avaliada pelos próprios adolescentes que ajudaram a construi-la.

\section{Interrelações: evasão, comunicação pública, adolescência e tecnologia}

Estudar, prevenir e atuar contra a evasão escolar significa perpassar um "vasto e intricado conjunto de circunstâncias individuais, institucionais e sociais" (DORE; LUSCHER, 2011, p. 777). A evasão é um problema cujo nível de complexidade revela-se incompatível com soluções simplistas ou definitivas. Não se trata da simples decisão de abandonar um curso, mas de um cumulativo processo de desengajamento do estudante da vida da escolar, afetado "por um conjunto de condições que se relacionam tanto ao estudante e a sua família, quanto à escola e à comunidade em que vive" (DORE; LUSCHER, 2011, p. 776). Considerando-se tantos agravantes, se propõe neste artigo, como caminho mais adequado para a evasão escolar, a prevenção.

Naturalmente, as recorrentes pesquisas dedicadas ao assunto não parecem gerar conhecimento suficiente para erradicar o fenômeno, nem mesmo em um único contexto. Assim, este estudo também não foi realizado com tal pretensão, mas busca apontar caminhos que contribuam para prevenir-se a evasão numa modalidade particular da educação profissional e tecnológica pública de nível técnico: o Ensino Médio Integrado (EMI).

O EMI é uma modalidade prioritária dos IFs (BRASIL, 2008), ao constituirse um modelo urgente e necessário à realidade da juventude brasileira, que precisa precocemente atuar no mundo do trabalho. O EMI "proporciona que os sujeitos se 
vejam tendo conhecimentos, sendo produtivos para a sociedade, ainda que as relações nesta sociedade tendam sempre à exclusão" (RAMOS, 2008, p. 22). Tal modalidade representa a busca dos IFs pelo rompimento com um modelo excludente de educação, dando lugar a um projeto de sociedade mais justa e integradora. Nesse sentido, vê-se a importância do EMI como objeto deste estudo, ao se compreender que a evasão escolar nesta etapa constitui, principalmente, um prejuízo de esfera social.

$\mathrm{Na}$ contramão desse prejuízo, encontra-se a comunicação pública, por natureza aliada à cidadania. É preciso reconhecer que o conceito desta forma de comunicação ainda está em processo de construção (BRANDÃO, 2009). Contudo, autores como López (2012) já observaram que, mesmo com todas as modificações que o conceito possa ter sofrido desde o seu surgimento, o benefício social foi seu primeiro objetivo. Ele observa, ainda, certo consenso literário em pelo menos três aspectos: a noção de comunicação associada à compreensão do público; a comunicação que opera em diferentes cenários, entre eles, o estatal, o público, o organizacional e o midiático e o conceito de comunicação pública vinculado a princípios como visibilidade, inclusão e participação. Todos os aspectos são considerados neste trabalho, com especial enfoque ao último, por compreender-se aqui que a grande contribuição da comunicação pública para o contexto estudado é a capacidade de favorecer a construção da cidadania pelo acesso à educação de qualidade. Este potencial fica mais óbvio na perspectiva de Brandão (2009), uma vez que, para a autora, o mais recente conceito de comunicação pública, ao representar também a preocupação das instituições com a cidadania, deixa claro que a cidadania deixa de ser compreendida como atitude passiva e ganha ares de participação e livre exercício de direitos e deveres. Para estes, só se está preparado quando existem condições de informação e comunicação.

Ademais, não basta cumprir a obrigatoriedade de prezar pela transparência das informações públicas, como determina e Lei de Acesso à informação (BRASIL, 2011), ou fazer da comunidade alvo de uma divulgação que ela pode não estar interessada em receber. Ainda que fosse deixada de lado toda a perspectiva social da comunicação pública, não se poderia desconsiderar a comunicação como um direito fundamental, garantido pela Constituição Federal (BRASIL, 1988) e pelo Estatuto 
da Juventude (BRASIL, 2013, p. 32). Conforme alerta Candau (2012 apud SILVA, PELISSARI; STEIMBACH, 2013), não basta construir um “arcabouço jurídico” (p. 717) cada vez mais amplo em relação aos direitos humanos, se eles não forem internalizados no imaginário social, nas mentalidades individuais e coletivas, de modo sistemático e consistente. Sobre tal necessidade de aplicação prática da lei, a organização Intervozes (2005), em seu relatório de pesquisa sobre direito à comunicação no Brasil, aponta atributos capazes de auxiliar na materialização da comunicação como um direito humano, a partir de estudo contemporâneo sobre a situação da comunicação no Brasil. Entre os principais atributos listados no relatório, consta o direito ao

acesso e pronta disponibilidade de informações públicas e governamentais, de modo abrangente, útil e rápido, especialmente no que concerne ao desenvolvimento e implementação de políticas e questões de interesse público, como saúde, segurança etc. (INTERVOZES, 2005, p. 9, grifo nosso)

A essa citação pode-se complementar: e à educação, como se pode deduzir da expressão interesse público.

Este tipo de apontamento sugere às instituições públicas uma revisão de suas práticas em comunicação, que precisam estar de acordo com as necessidades de quem atende ou busca atender. Consequentemente, estas instituições precisam abandonar a cômoda posição de divulgadoras, e se dispor a conhecer seu público, identificar seus interesses, hábitos relacionados à forma como se comunicam enfim, ouvi-los — para, então, estabelecer uma comunicação legítima e respeitosa quanto aos interesses da sociedade.

A aposta na interação com estudantes, público-alvo do ensino médio integrado à educação profissional e tecnológica (FRIGOTTTO, CIAVATT'TA 2004) e, portanto, sujeitos que ainda não fazem parte da instituição escolar, com o objetivo de prevenir-se a evasão, relaciona-se ao fato do engajamento acadêmico e social ser um fator decisivo de permanência (DORE; LUSCHER, 2011). Aproximar alunos em potencial é uma ação que pode ser compreendida como a antecipação deste engajamento. Ao trabalhar a comunicação pública e buscar se aproximar dos alunos em potencial, a instituição estaria também antecipando um vínculo, permitindo que o estudante se identifique — ou não — com sua proposta e seus cursos. Favoreceria 
o exercício da autonomia e reflexão, além do comportamento exploratório, contribuindo para que os adolescentes externos construam a cidadania, e evitem ou minimizem as frequentes investidas em trajetórias que podem não representar os verdadeiros anseios dos estudantes em nível médio.

Contudo, é comum os sujeitos desta faixa etária ${ }^{1}$ serem vistos como um "problema" (LIMA, 2004, p. 94). Tal estigma pode significar um empecilho à valorização das potencialidades de cada um deles enquanto educandos. Assim, Frigotto e Ciavatta (2004) apontam a empatia como um caminho para os educadores: pensar a política de ensino médio partindo dos próprios sujeitos adolescentes — seus interesses, suas dificuldades, seus sonhos.

Se existem lacunas de comunicação entre uma instituição e seu público, fazse necessário conhecer que tipos de canais e mídias estes adolescentes utilizam e consideram interessantes, para que seja possível estabelecer o diálogo e alcançar a abertura necessária para se promover o conhecimento entre eles. Não se trata da comunicação em via de mão única — "como se os cidadãos fossem meros objetos de comunicados" (LOPES, 2007) — mas sim de interação ${ }^{2}$; de reciprocidade; da “criação de formas de acesso e participação" (LOPES, 2007, p. 68).

A interação é, atualmente, amplamente facilitada pelas Tecnologias de Informação e Comunicação (TICs), já incorporadas à vida moderna e necessárias para agilizar um "cotidiano imediatista” (SABOIA; VIVA; VARGAS, 2013). E isto ocorre, ou deveria ocorrer, também na relação entre estudante e escola. Vive-se a chamada Era do Conhecimento, na qual a tecnologia

possibilita a expressão de novas atividades, novos formatos de interação social, ampliação dos locais, formatos e estrutura do processo de ensino e aprendizagem, ampliando a percepção da sala de aula e da interação aluno-professor e alunoaluno (SABOIA, VIVA E VARGAS, 2013, p. 3).

Nesse sentido, os produtos e serviços inovadores ligados aos smartphones, unindo características como instantaneidade e portabilidade, apresentam enorme potencial de captarem atenção da faixa etária aqui estudada. Pesquisa divulgada pelo

\footnotetext{
${ }^{1}$ Consideram-se adolescentes pessoas entre 12 e 18 anos de idade (BRASIL, 1990).

2 Conceito compreendido segundo 0 dicionário Michaelis online: $<$ http://michaelis.uol.com.br/busca?r=0\&f=0\&t=0\&palavra=intera\%C3\%A7\%C3\%A30>
} 
Comitê Gestor da Internet no Brasil (CRESCE, 2018), observou um crescimento no uso de dispositivos móveis entre crianças e adolescentes para acessar a Internet. Se em 2012, 21\% acessaram a rede por meio do celular, em 2017 são 93\%, o que representa 23 milhões de crianças e adolescentes. A pesquisa estima ainda que, em 2017, 44\% destes usuários de Internet acessaram a rede exclusivamente por meio de telefones celulares, o que representa 11 milhões de jovens. Segundo essa pesquisa, o celular é o principal meio de acesso para crianças e adolescentes da área rural (57\%), do Norte $(59 \%)$ e classe DE (67\%).

É importante lembrar que o público do EMI é composto integralmente por "nativos digitais" (SABOIA, VIVA E VARGAS, 2013, p. 3), pessoas que já incorporam dispositivos móveis como uma extensão do lar ou do seu próprio corpo. A esse respeito, os autores citam como como principais preferências destes jovens: informações rápidas e de múltiplas fontes; som e vídeo, ao invés de texto; interação simultânea com muitas pessoas; e aprendizagem de coisas relevantes, instantaneamente úteis, lúdicas e divertidas. Experiências recentes confirmam tais apontamentos.

Relatos de experiências (ALENCAR, 2015; SILVA, 2016a, SILVA, 2018) comprovam que os smartphones podem ser de grande valia na Educação e na aproximação entre as instituições educacionais e adolescentes público-alvo do EMI. Tais recursos tecnológicos não devem ser vistos, portanto, como inimigo dos professores e das escolas, mas como fortes aliados da educação, inclusive no combate à evasão escolar.

Entretanto, no Banco Internacional de Objetos Educacionais ${ }^{3}$ não foram encontrados produtos similares à proposta em questão. Nota-se, ao contrário, uma recorrência de aplicativos voltados ao estudante, com facilidades de acesso a notas, informações sobre eventos, entre outros, mas nenhuma tecnologia interativa similar voltada ao candidato em potencial.

\footnotetext{
${ }^{3}$ Disponível em: <http://portal.mec.gov.br/seed-banco-internacional-de-objetos-educacionais>. Acesso em: 22 Ago. 2018
} 


\section{Diálogo com adolescentes ligados ao contexto do Campus Rio Pomba}

Apesar do forte indicativo de que um aplicativo para smartphones seria capaz de auxiliar na comunicação entre o Campus Rio Pomba e seus futuros alunos, fez-se necessária uma confirmação empírica voltada ao microuniverso regional do contexto estudado, bem como a descoberta de como funcionaria esta tecnologia. Assim, foi realizada uma entrevista coletiva com um grupo de 20 adolescentes externos ao IF Sudeste MG, com idade entre 14 e 17 anos, atendidos pela Prefeitura Municipal de Rio Pomba por sua situação de vulnerabilidade social ${ }^{4}$. As respostas, interpretadas por análise de conteúdo à luz de Laurence Bardin (2011), mostram-se ricas em informações e levam a diversas conclusões ${ }^{5}$. Entretanto, no presente trabalho, foi necessário resumir tal processo, voltando-o ao objetivo principal, de verificar se um aplicativo para celular voltado a candidatos do IF Sudeste MG teria chances de ser utilizado por estudantes público-alvo da EPT.

Na questão referente à imagem institucional, houve diversos indícios de que os estudantes não sabem, de fato, o que é o IF Sudeste MG. Após várias frases de estímulo da pesquisadora e momentos de silêncio, alguns afirmaram não saber responder, sendo que as poucas respostas subsequentes mais se assemelhavam a indagações: Ensino Superior? Ensino Médio? Outras associações foram feitas em tom de incerteza e/ ou associadas a terceiros: a minha prima estudou lá e falou que era bom.

Ainda assim, foi possível inferir que a imagem do IF Sudeste MG diante dos estudantes entrevistados é positiva, mas não supera uma suposta dificuldade de ingressar e de se manter nos cursos, levando a crer que a qualidade, na visão deles, não é suficiente para encarar os desafios: Aí vem na minha cabeça que eu não vou nunca pra lá não, que é muito difícil. O discurso ainda denota conformação em relação à própria situação socioeconômica — ou mesmo intelectual — supostamente vista

\footnotetext{
${ }^{4}$ Para a realização da entrevista, foi firmada parceria entre o IF Sudeste MG e a Secretaria de Assistência Social de Rio Pomba (CRAS).

${ }^{5}$ Essas discussões encontram-se disponíveis no trabalho "É este curso que eu quero": a comunicação publica na promoção de conhecimento e prevenção da evasão no Ensino Médio Integrado, apresentado como requisito parcial à obtenção do título de mestre pelo Programa de Mestrado em Educação Profissional e Tecnológica (ProfEPT) do IF Sudeste MG.
} 
como empecilho aos estudos na referida instituição. Assim, percebe-se a relevância do marketing de referência, conhecido também como boca-a-boca, em detrimento da comunicação oficial de iniciativa do Campus Rio Pomba.

Assim, tornou-se mais óbvia a influência de informações não oficiais na formação da imagem institucional e, consequentemente, na avaliação que os estudantes fazem sobre ser possível ou vantajoso estudar no IF Sudeste MG: Às vezes é tão fácil, mas aí vem as pessoas direm: vai não, que é difícil / Um monte de gente desanimando a gente. E, novamente, o embate sobre ser difícil — ou não — se coloca como determinante, embora haja suspeita quanto à veracidade da caracterização: É... Às vezes nem é tão difícil assim.

Encontramos estudantes capazes de listar os cursos ofertados pelo Campus Rio Pomba, mas os descrevem de maneira insegura e com poucas ideias superficiais. Normalmente, estas ideias refletem estereótipos de profissões: Agropecuária mexe com trator. É possível que este tipo de concepção interfira no interesse do estudante pelo curso, ao constituir uma crença não necessariamente embasada. No exemplo da Agropecuária, a característica se confirma, mas o curso e a profissão de técnico extrapolam o uso do trator em muitos âmbitos (IF SUDESTE MG, 2018).

Surgiram, ainda, outros problemas, como a falta de interesse (vontade) por parte do público e áreas de formação inadequadas às preferências individuais do grupo: A maioria dos cursos que a gente quer, lá não tem. Tomado de forma isolada, este discurso poderia simplesmente indicar que não houve identificação com a área, mas o grupo estudado dá indícios de não conhecer a identidade dos cursos: Só [sei] o que ouvi falar da boca dos outros. Portanto, adquirindo conhecimento, há chances de identificação e dos estudantes descobrirem que têm interesse, sim, em uma ou mais opções de formação. Por outro lado, se a falta de identificação se confirma, mesmo após o conhecimento sobre os cursos proposto neste estudo, vêm à tona outros questionamentos: o Campus está realmente atendendo ao entorno produtivo local? Seus cursos estão de acordo com as demandas regionais, conforme determina a Lei de Criação dos IFs (BRASIL, 2008)? Estão sendo realizados estudos de demanda? O Campus está realmente próximo da sociedade, dialogando com o público-alvo a quem se destina? Registram-se aqui indagações motivadoras de novas pesquisas. 
Quando questionados sobre o desejo de conhecerem mais sobre o IF Sudeste MG, as respostas positivas foram praticamente unânimes. Contudo, para os estudantes, o EMI em particular é um empecilho, devido ao horário integral. Os entrevistados indicaram não poderem deixar de trabalhar para se dedicar aos estudos. Nem todo mundo ganha bolsa. Nenhum outro problema relacionado às especificidades do EMI apareceu, refletindo o fato do público-alvo do Ensino Médio no Brasil ser constituído por jovens "de classe popular, filhos de trabalhadores assalariados ou que produzem a vida de forma precária por conta própria [...]” (FRIGOTTO, CIAVATTA, 2004, p. 57). Ao assumir um compromisso social, os IFs vêm ao encontro destes estudantes de baixa renda, muito embora a assistência estudantil como parte de sua política igualitária precise ser aprimorada, segundo os adolescentes.

Ao serem interrogados sobre o interesse no curso de Agropecuária, nenhum estudante se manifestou. Este comportamento é explicado em seguida pela representante da Prefeitura Municipal responsável pelo projeto do qual o grupo participa. Segundo ela, os adolescentes não têm conhecimento: Acham que é mais trabalhar capina. E, por isso, não têm expectativa.

Questionou-se se um aplicativo para celular seria útil aos adolescentes, no sentido de promover conhecimento sobre o Campus Rio Pomba. E assim confirmou-se o potencial funcional do aplicativo pela manifestação favorável e entusiasmada do grupo entrevistado. Entre as funcionalidades propostas para o aplicativo, destacou-se um possível chat entre usuários externos ao IF Sudeste MG e alunos já matriculados, de maneira que a experiência destes possa ser compartilhada diretamente com os alunos em potencial. Observa-se, ainda, que no aplicativo idealizado, textos deveriam ser usados em quantidades moderadas e substituídos por vídeos de curta duração tanto quanto possível (SABOIA, VIVA; VARGAS, 2013). Foi evidenciada a importância da honestidade das informações disponibilizadas, especialmente quanto aos pontos negativos de cada curso: Tem que ter as desvantagens também, né? Nem todo curso é perfeito. Parece óbvio que os cidadãos devam exercer seu direito de escolher um curso com base em informações verídicas, mas a divulgação de "verdades truncadas (incompletas)" também é considerada crime (INTERVOZES, 2005). Ademais, a exigência da estudante entrevistada também 
remete ao compromisso da comunicação pública em prezar pelo interesse geral, ouvindo as demandas da coletividade (BRANDÃO, 2009).

Em suma, a entrevista com alunos da rede pública, não matriculados no IF Sudeste MG, foi marcada pela necessidade de muitos estímulos por parte da pesquisadora, revelando que o grupo estava pouco à vontade para falar do assunto. O distanciamento entre os estudantes e a instituição foi comprovado por incertezas e respostas em tom de indagação. Mas de uma forma geral, os alunos têm uma imagem positiva da instituição, pois se referem à qualidade do ensino em vários momentos da entrevista; mas esta mesma característica positiva é contraposta ao empecilho de ser difícil de ingressar e permanecer — caracterização tão recorrente quanto a anterior. Tais questões referentes à imagem, capazes de influenciar as decisões estudantis, traduzem a formação de um conceito de IF Sudeste MG baseado em informações não oficiais e que não representam a identidade da instituição. Por outro lado, os adolescentes manifestam interesse em conhecer a identidade da instituição. No caso específico do EMI, o interesse não é suficiente, pois cursá-lo os obrigaria a abandonar suas fontes de renda e eles não hesitam em se manter empregados. Em se tratando do desinteresse pela Agropecuária, em especial, a desinformação pode ser um fator causal a ser combatido por meio do aplicativo. Diante de tais questões, o potencial desta inovação tecnológica se reitera.

\section{Rolê no IF: uma proposta para o EMI no Campus Rio Pomba}

O aplicativo foi denominado Rolê no IF como forma de designar, em linguagem coloquial, um passeio virtual e descontraído pela instituição. Seu objetivo, enquanto protótipo a ser ampliado num segundo momento ${ }^{6}$, é promover conhecimento sobre o curso de Agropecuária, dialogando com o público-alvo desta modalidade e favorecendo o engajamento (DORE; LUSCHER, 2011) antecipado com o Campus Rio Pomba, a proposta de formação representada pelo EMI e com a

\footnotetext{
${ }^{6}$ A proposta de ampliação do protótipo para todo o EMI do Campus Rio Pomba veio a ser aprovada em edital específico da Pró-Reitoria de Pesquisa e Inovação do IF Sudeste MG. O projeto encontra-se em execução até agosto de 2020.
} 
carreira profissional referente a esta proposta. Retoma-se aqui uma afirmação de Bardagi (2007) que justifica a aplicação do referido produto na EPT, ao dialogar com a natureza libertária do Ensino Médio Integrado. Para a autora, a escola deve promover um espaço que

possibilita a expressão de novas atividades, novos formatos de interação social, ampliação dos locais, formatos e estrutura do processo de ensino e aprendizagem, ampliando a percepção da sala de aula e da interação aluno-professor e alunoaluno (SABOIA; VIVA; VARGAS, 2013, p. 3).

A partir da Figura 1, iniciamos a representação do produto resultante destas e outras diretrizes obtidas ao longo da pesquisa. Ao utilizar o Rolê no IF pela primeira vez, o usuário visualiza a tela reproduzida na Figura 1 e, em poucos segundos, será direcionado à tela de login (Figura 2). O usuário poderá usar sua conta do Facebook para a entrada, poupando-lhe tempo de cadastro e permitindo a comunicação e o compartilhamento de informações em geral entre o aplicativo e a rede social.

Figura 1 - Tela de abertura do aplicativo Rolê no IF
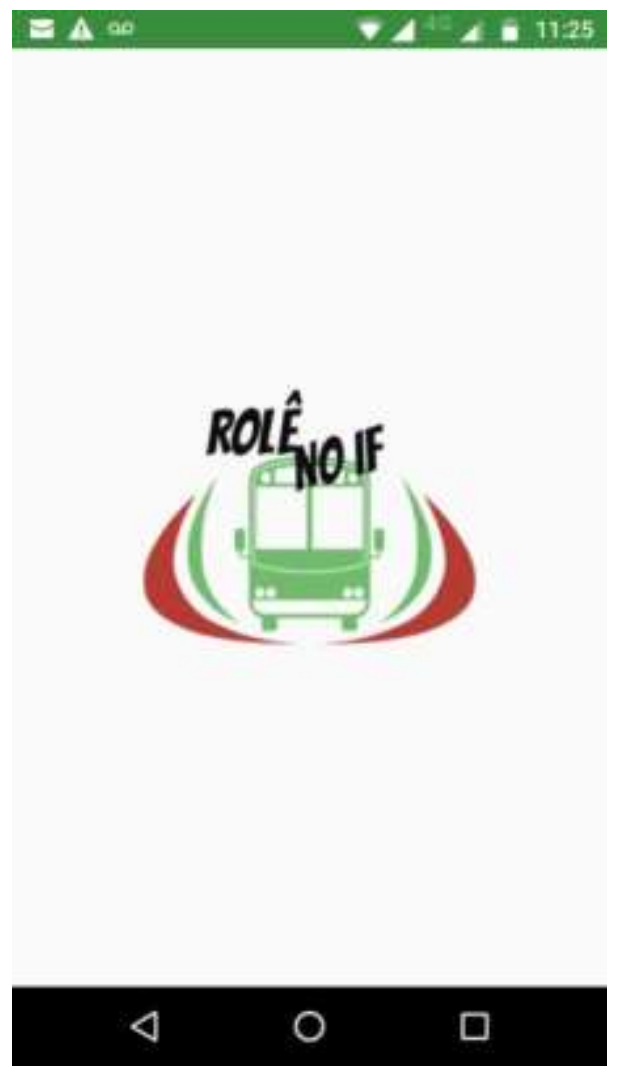

Fonte: acervo da pesquisadora. 
Figura 2 - Tela de login do aplicativo Rolê no IF

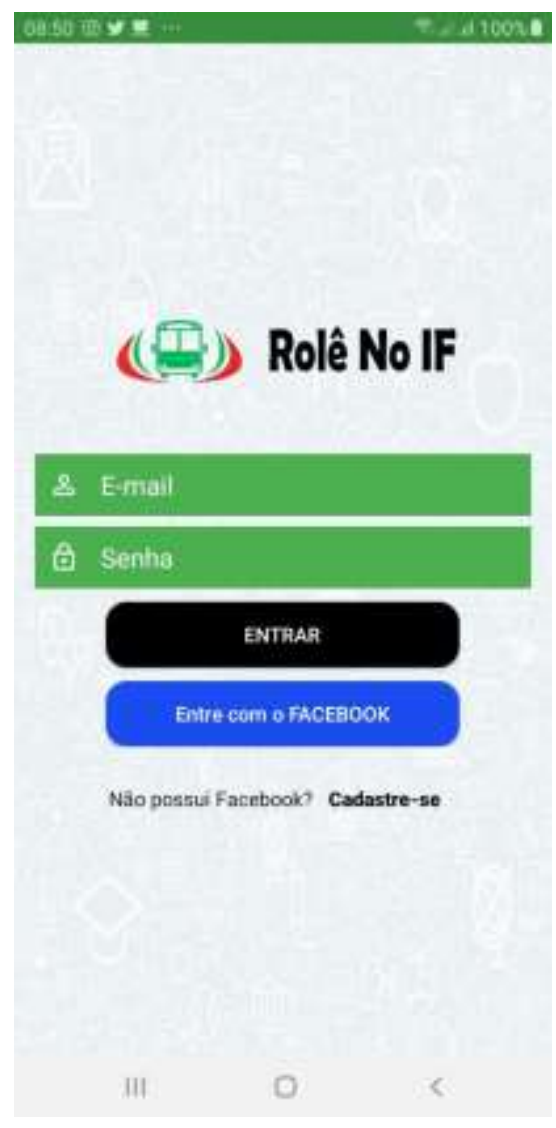

Fonte: acervo da pesquisadora.

Em seguida, o usuário será conduzido a responder um quiz, exemplificado na Figura 3. Nesta primeira experiência, o usuário irá responder a uma série de perguntas sobre suas preferências pessoais. As respostas são associadas a preferências por cursos técnicos integrados do Campus Rio Pomba Agropecuária, Alimentos, Meio Ambiente, Informática e Zootecnia — conforme as habilidades normalmente exigidas ou desenvolvidas em cada um deles ${ }^{7}$.

\footnotetext{
${ }^{7}$ Pelo fato do aplicativo ser fruto de estudo de caso sobre o curso de Agropecuária, esta função havia sido pensada de forma mais limitada, com o título "O curso de Agropecuária combina com você?". Todavia, ao longo do desenvolvimento do protótipo, a Pró-Reitoria de Pesquisa do IF Sudeste MG aprovou (por meio do edital 3/2018) uma proposta de ampliação da abrangência do aplicativo a todos os técnicos integrados. Por esse motivo, criou-se a função Quiz, na tentativa de tornar mais rica a experiência do usuário desde a primeira versão.
} 
Figura 3 - Exemplo da função Quiz do aplicativo Rolê no IF

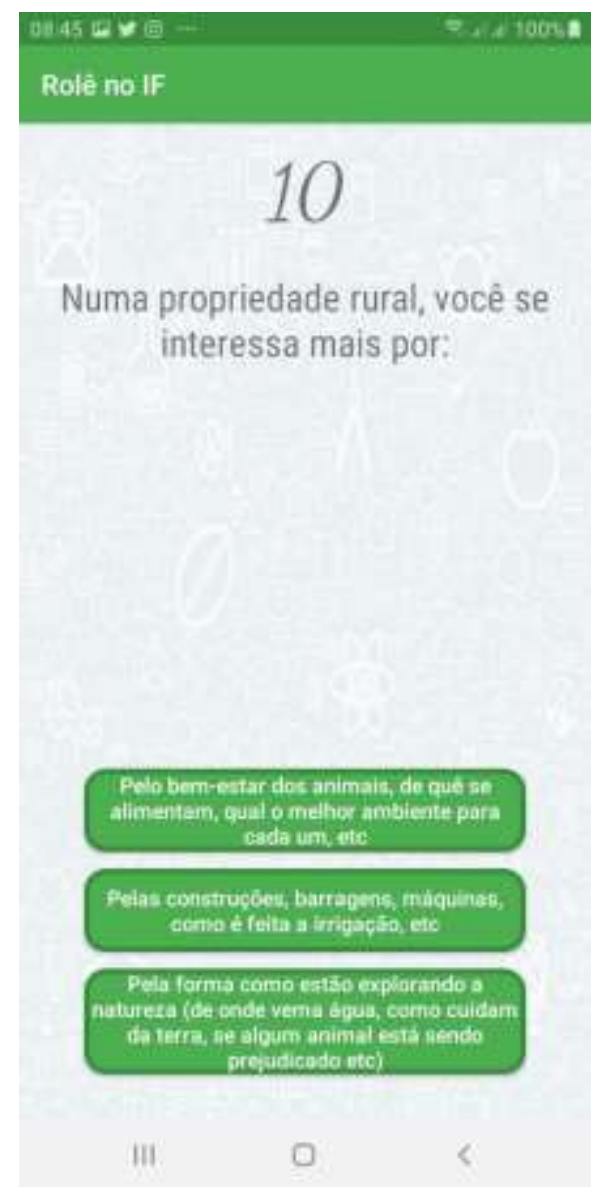

Fonte: acervo da pesquisadora.

As perguntas do quiz foram elaboradas e propostas pelos pesquisadores, após o diálogo com psicólogas da instituição, pesquisa sobre os cursos e validação com adolescentes estudantes do EMI no Campus Rio Pomba. O usuário terá como resultado do quiz uma sugestão de curso supostamente compatível com suas aptidões, seu gosto e com as características pessoais informadas.

Ao clicar no curso que aparece como resultado, o estudante será convidado a ler uma breve descrição textual do curso sugerido no aplicativo e, no caso do curso de Agropecuária, será conduzido a explorar outras funções não textuais, como vídeos e imagens. As demais funcionalidades do aplicativo encontram-se descritas uma a uma nos Quadros 1, 2 e 3, em que são também evidenciados os fundamentos de justificativa de cada botão, na tentativa de ampliarem-se as chances de compreensão do produto e da experiência proporcionada por este. 
Figura 4 - Exemplo de resultado da função Quiz

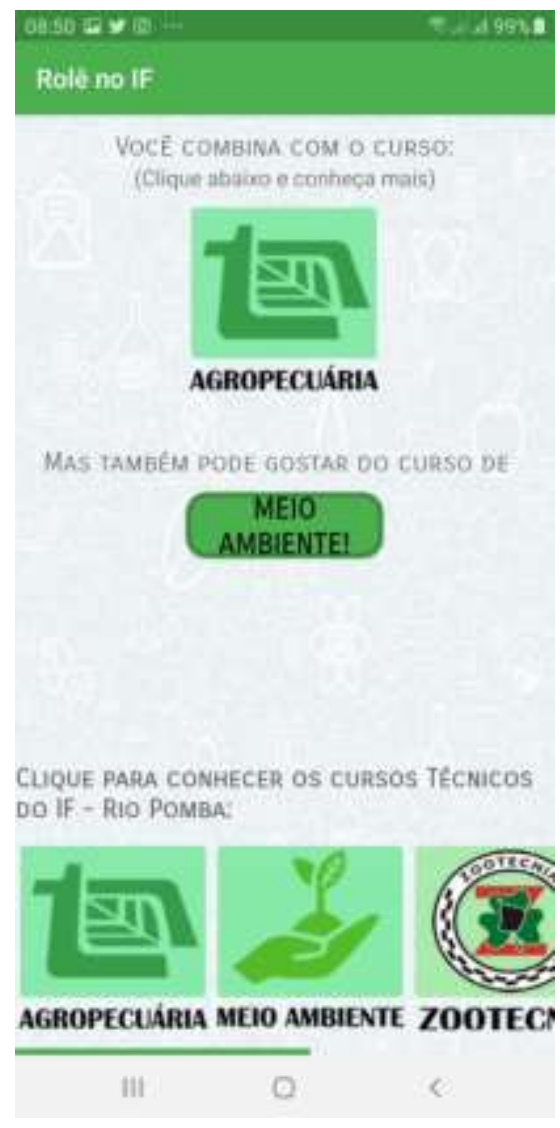

Fonte: acervo da pesquisadora.

Quadro 1 - Funcionalidades, telas e justificativas do aplicativo Rolê no IF referentes tanto ao IF Sudeste MG - Campus Rio Pomba quanto ao curso de Agropecuária

(continua)

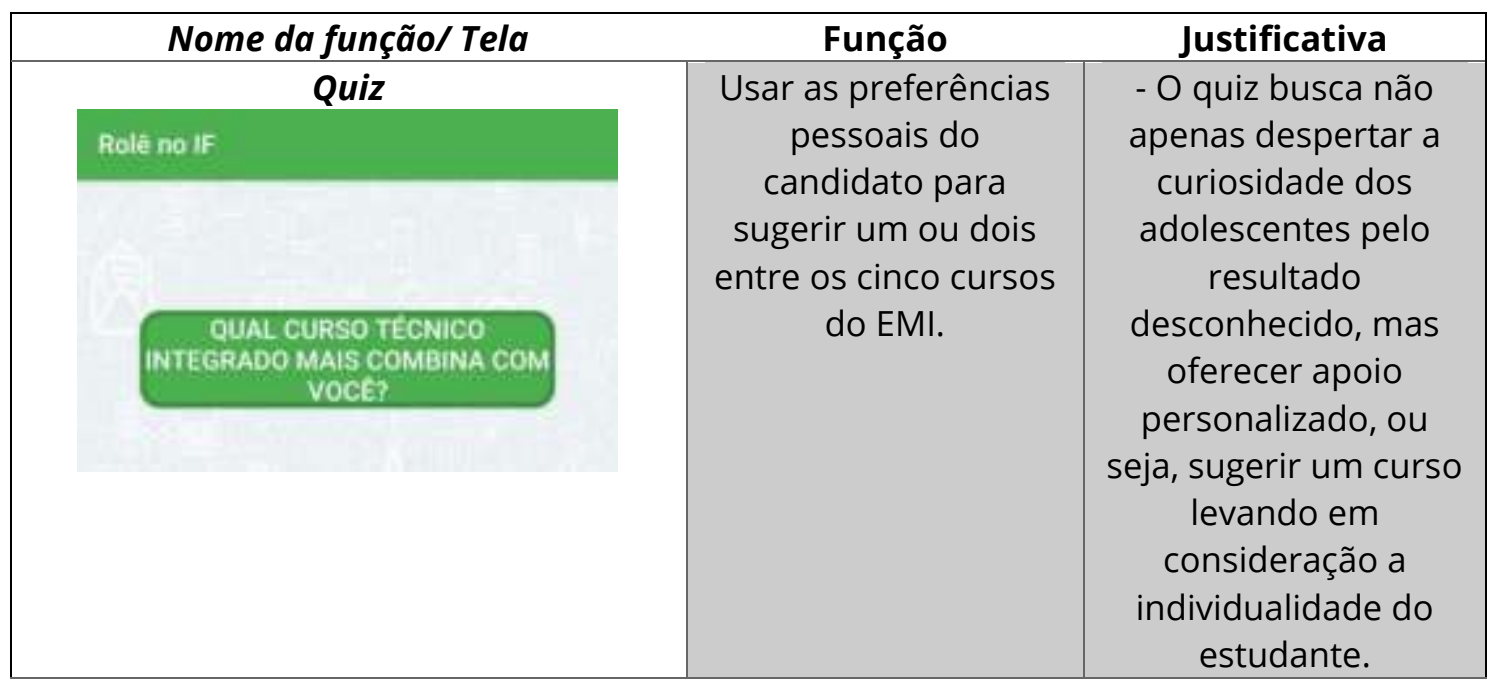


Quadro 1 - Funcionalidades, telas e justificativas do aplicativo Rolê no IF referentes tanto ao IF Sudeste MG - Campus Rio Pomba quanto ao curso de Agropecuária

(continuação)

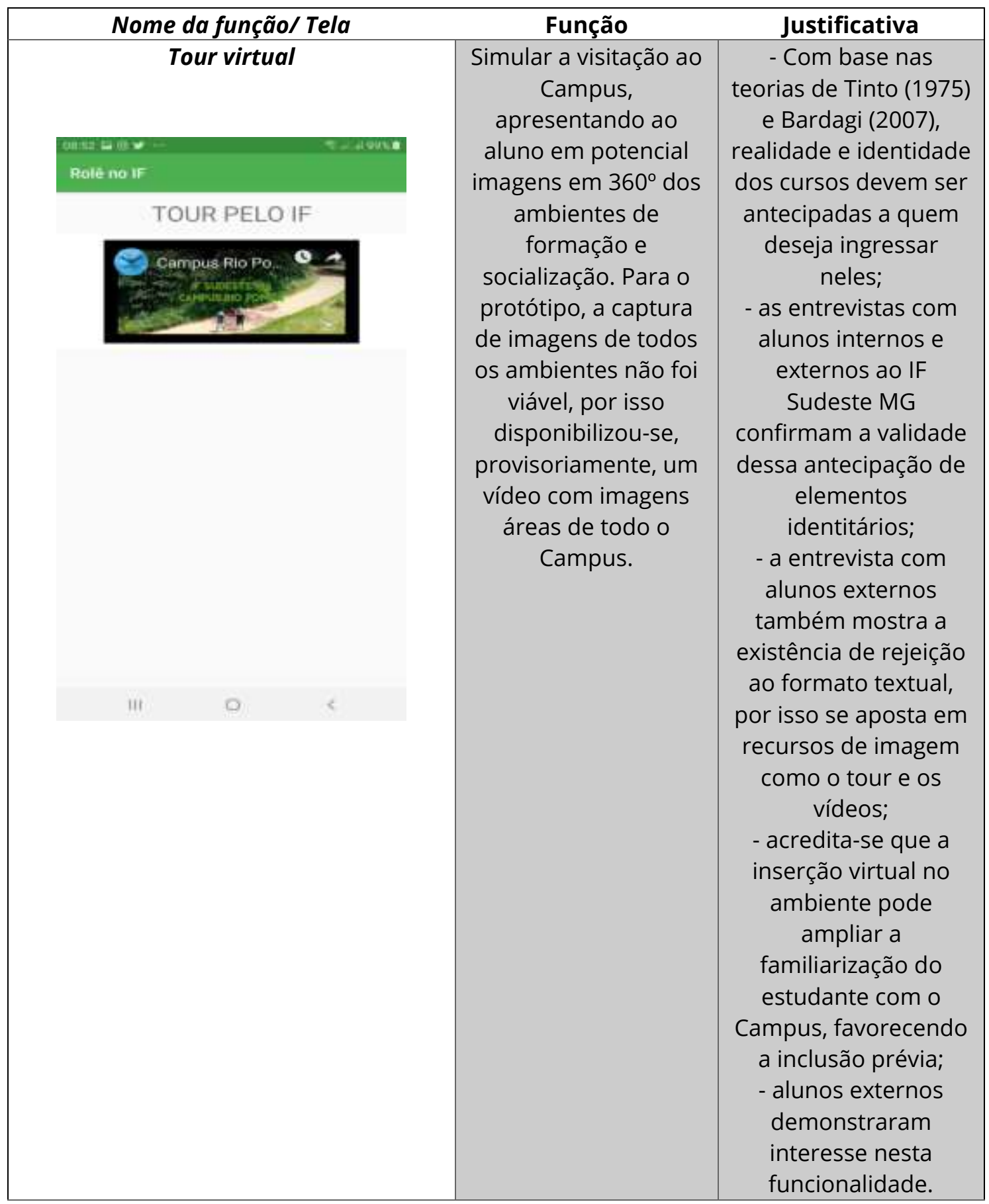


Quadro 1 - Funcionalidades, telas e justificativas do aplicativo Rolê no IF referentes tanto ao IF Sudeste MG - Campus Rio Pomba quanto ao curso de Agropecuária

(conclusão)

\begin{tabular}{|c|c|c|}
\hline Nome da função/ Tela & Função & Justificativa \\
\hline 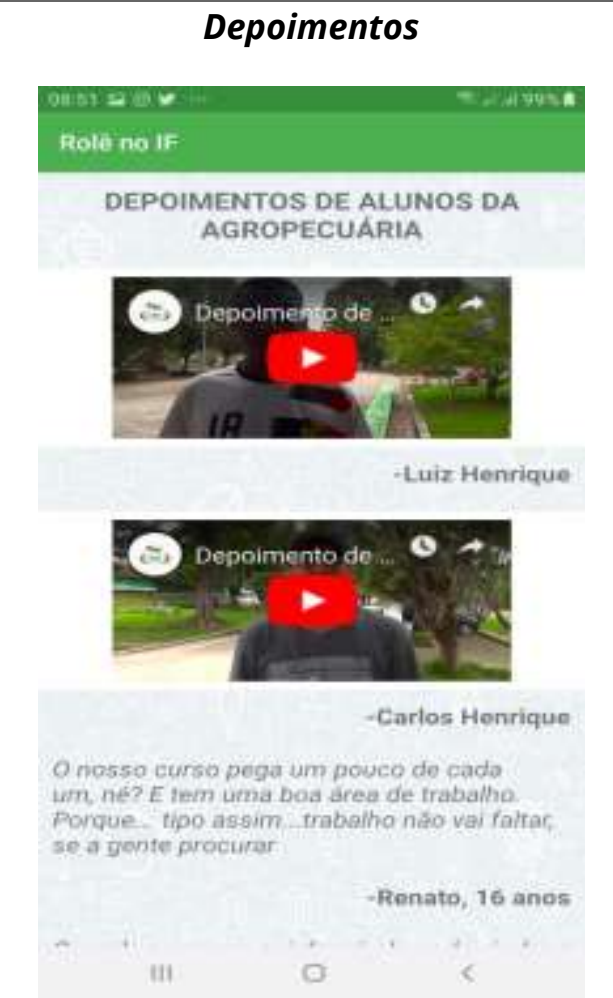 & $\begin{array}{l}\text { Disponibilizar } \\
\text { depoimentos reais, } \\
\text { produzidos por } \\
\text { alunos e ex-alunos, } \\
\text { em formato de vídeo } \\
\text { (preferencialmente) } \\
\text { ou pequenos } \\
\text { parágrafos. Oferecer } \\
\text { a possibilidade de } \\
\text { contato entre os } \\
\text { usuários do aplicativo } \\
\text { e os depoentes (vide } \\
\text { função Chat). }\end{array}$ & $\begin{array}{l}\text { - Esta função se } \\
\text { justifica por criar } \\
\text { identidade e } \\
\text { aproximações entre } \\
\text { público-alvo, } \\
\text { estudantes e } \\
\text { egressos. Valoriza as } \\
\text { informações que já } \\
\text { demonstraram largo } \\
\text { alcance enquanto } \\
\text { marketing de } \\
\text { referência - ou boca a } \\
\text { boca. Tem mais } \\
\text { chances de aproximar } \\
\text { os estudantes } \\
\text { externos da } \\
\text { instituição devido à } \\
\text { similaridade entre } \\
\text { interlocutores que se } \\
\text { encontram na mesma } \\
\text { faixa etária. }\end{array}$ \\
\hline Coisa número 4: & $\begin{array}{l}\text { Antecipar, por meio } \\
\text { de vídeos descritivos } \\
\text { em linguagem } \\
\text { informal, aspectos da } \\
\text { identidade do curso } \\
\text { de Agropecuária e do } \\
\text { Campus Rio Pomba, } \\
\text { incluindo-se aqueles } \\
\text { que podem ser vistos } \\
\text { como negativos. }\end{array}$ & $\begin{array}{l}\text { - Segundo Bardagi } \\
\text { (2007, p. 61), } \\
\text { "antecipar a } \\
\text { ocorrência de um } \\
\text { evento estressante } \\
\text { permite que se inicie } \\
\text { um processo } \\
\text { preparatório que } \\
\text { reduz os efeitos } \\
\text { nocivos do } \\
\text { acontecimento"; } \\
\text { - alunos internos ao IF } \\
\text { Sudeste MG } \\
\text { apontaram } \\
\text { espontaneamente } \\
\text { que antecipar } \\
\text { desafios seria capaz } \\
\text { de reduzir a evasão } \\
\text { causada pela falta de } \\
\text { identificação. }\end{array}$ \\
\hline
\end{tabular}

Fonte: Acervo da pesquisadora (2018) 
Quadro 2 - Funcionalidades, telas e justificativas do aplicativo Rolê no IF voltadas especificamente ao curso de Agropecuária

\begin{tabular}{|c|c|c|}
\hline Nome da função/ Tela & Função & Justificativa \\
\hline 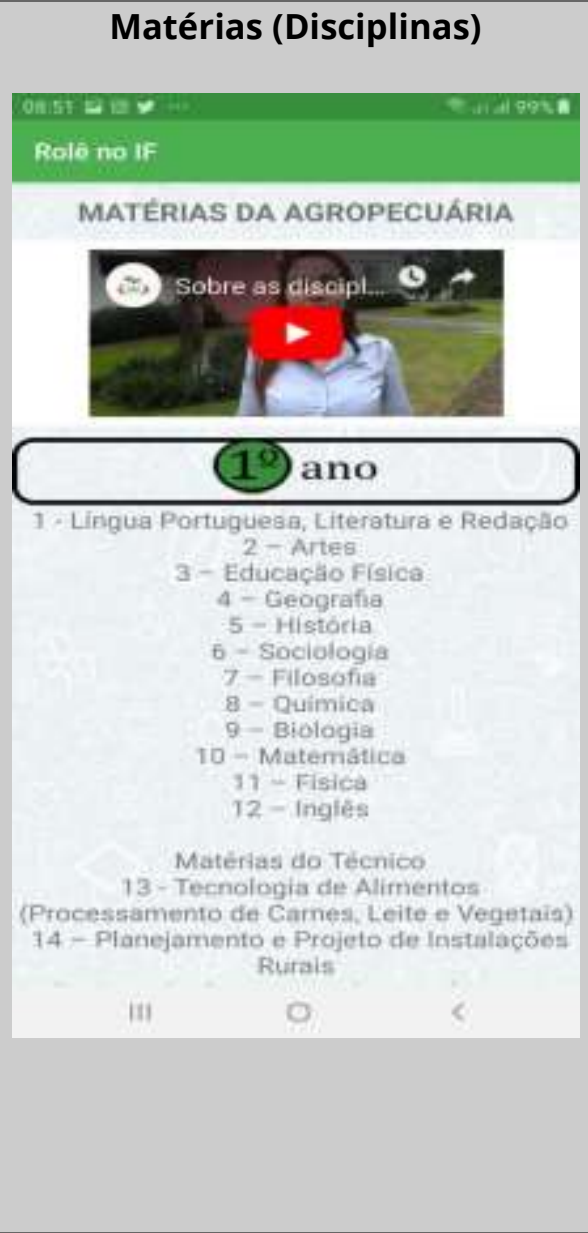 & $\begin{array}{l}\text { Informar, por meio } \\
\text { de listagem } \\
\text { simples, de } \\
\text { maneira objetiva e } \\
\text { direta, quais serão } \\
\text { as disciplinas } \\
\text { estudadas em cada } \\
\text { etapa do curso }\end{array}$ & $\begin{array}{l}\text { - as entrevistas com } \\
\text { alunos externos e internos } \\
\text { ao IF Sudeste MG } \\
\text { confirmam a validade da } \\
\text { antecipação de elementos } \\
\text { identitários; } \\
\text { - o site institucional não } \\
\text { oferece acesso direto a } \\
\text { esta relação, o que pode } \\
\text { ser um fator de } \\
\text { distanciamento; } \\
\text { - alunos internos } \\
\text { demonstraram que } \\
\text { gostariam de ter tido } \\
\text { acesso a estas } \\
\text { informações e } \\
\text { demonstraram } \\
\text { desconhecimento quanto } \\
\text { à possibilidade de acessá- } \\
\text { las no site; } \\
\text { - alunos externos ao IF } \\
\text { sudeste MG } \\
\text { demonstraram interesse } \\
\text { em conhecer as } \\
\text { disciplinas a serem } \\
\text { cursadas durante o curso. }\end{array}$ \\
\hline 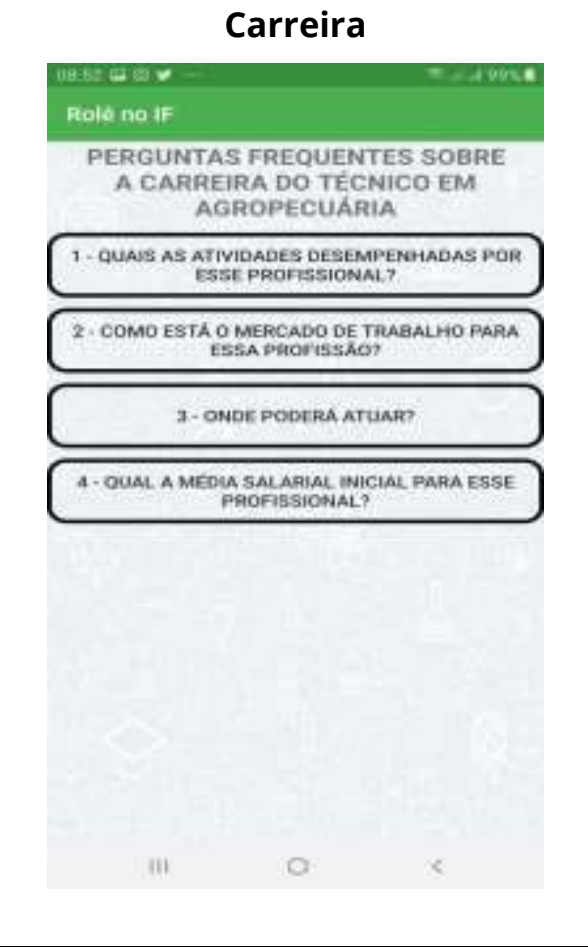 & $\begin{array}{l}\text { Apresentar, por } \\
\text { meio de vídeos e } \\
\text { texto, a realidade } \\
\text { do mundo do } \\
\text { trabalho no qual o } \\
\text { futuro profissional } \\
\text { ingressará e os } \\
\text { vínculos entre os } \\
\text { indivíduos e as } \\
\text { ocupações. }\end{array}$ & $\begin{array}{l}\text { - Bardagi (2007) destaca a } \\
\text { importância de salientar } \\
\text { as dimensões emocionais } \\
\text { positivas do trabalho; ela } \\
\text { também aponta a } \\
\text { necessidade de } \\
\text { possibilitar aos } \\
\text { adolescentes uma } \\
\text { conexão entre a profissão } \\
\text { e a experiência do curso, } \\
\text { pelo fato da primeira } \\
\text { parecer muito distante; } \\
\text { - com base em Tinto } \\
\text { (1975), conclui-se que criar } \\
\text { expectativas positivas e } \\
\text { motivadoras favorece o } \\
\text { comprometimento com a } \\
\text { carreira e, } \\
\text { consequentemente, com o } \\
\text { curso. }\end{array}$ \\
\hline
\end{tabular}

Fonte: acervo da pesquisadora. 
Quadro 3 - Funcionalidades, telas e justificativas do aplicativo Rolê no IF diretamente relacionadas à interatividade

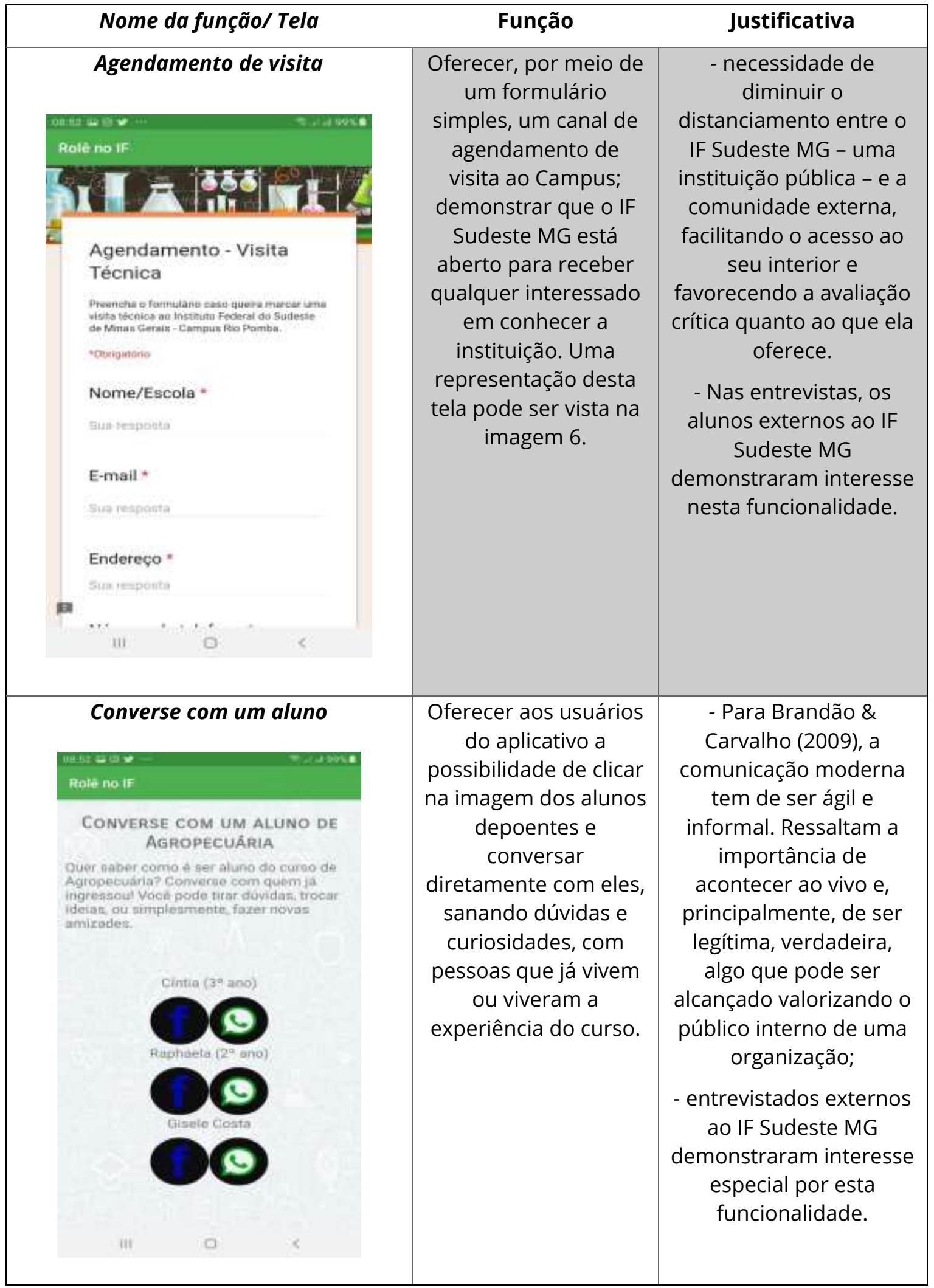

Fonte: Acervo da pesquisadora. 
Assim como nas experiências similares vivenciadas por outros autores (ALENCAR et al, 2015; SILVA, 2016b; SILVA, 2018), a dinâmica de alimentação baseia-se na interatividade. A proposta é de que os próprios alunos do IF possam inserir depoimentos e avaliar o curso que estão fazendo e, de forma complementar, responder dúvidas de quem está interessado em ingressar. Embora não seja este o objetivo do aplicativo, gestores poderão tomar conhecimento das avaliações para identificar e solucionar problemas pontuais. Obviamente, a manutenção do aplicativo demandará esforços permanentes de servidores da instituição, seja para o agendamento de visitas, para moderação de avaliações ou, ainda, para comunicar sobre as funcionalidades aos alunos e explicar a importância da colaboração de cada discente.

\section{Resultados da validação do aplicativo}

Para a validação do aplicatico, foi realizada uma avaliação quantitativa e qualitativa das respostas dos estudantes externos ao IF Sudeste MG sobre a experiência de uso do aplicativo Rolê no IF. Ela foi baseada em 17 respostas, obtidas voluntariamente, por questionário on-line enviado aos adolescentes por Whatsapp e também com respostas orais obtidas de entrevista não estruturada com o grupo de estudantes. O conjunto de resultados faz-se de extrema importância para a pesquisa em questão, por refletirem a visão de um público especialmente interessante no que se refere aos objetivos sociais do aplicativo e do estudo como um todo.

Segundo a avaliação dos estudantes, o aplicativo fora classificado como satisfatório por $24 \%$, excelente por $47 \%$ e moderado para $29 \%$ dos participantes. Assim, os dados quantitativos apontam que $71 \%$ dos participantes aprovaram o aplicativo. Apesar de haver críticas, eles reconheceram o cumprimento da proposta principal do aplicativo, de informar e levar conhecimento: pra quem tem interesse, vale a pena; entrar já sabendo do que que vai passar lá.

Eles ainda avaliaram positivamente a linguagem utilizada, afirmando terem entendido tudo que [os desenvolvedores] queriam passar e afirmaram não ter tido dificuldades em navegar pelos recursos do app. 
Faz-se importante destacar aqui que, apesar das explicações orais aos participantes quanto ao objetivo e ao contexto de desenvolvimento do aplicativo, percebeu-se que uma parcela dos alunos não compreendeu o motivo do Rolê no IF se referir, prioritariamente, a apenas um curso. Assim, uma das principais críticas e pedidos de melhoria foi com relação à falta de variedade: tinha que ter todos os cursos lá pra gente ver. É provável que as avaliações demonstrassem maior aceitação, se isto não se caracterizasse como uma falha na visão dos usuários. Por outro lado, esta situação experimental encarada como defeito também revela uma curiosidade a ser satisfeita: conhecer mais cursos. E, constitui, portanto, justificativa para a transformação do protótipo em canal de comunicação institucional.

Em relação ao poder do aplicativo como fonte deconhecimento sobre o curso de Agropecuária, apenas 6\% dos participantes respondeu negativamente. Logo 94\% dos estudantes considerou que o aplicativo foi capaz de apresentar o curso e aproximá-los da instituição, cumprindo assim sua função de promover o conhecimento da identidade do curso de Agropecuária.

Gráfico 1 - Depois de usar o aplicativo, sua visão sobre o IF mudou?

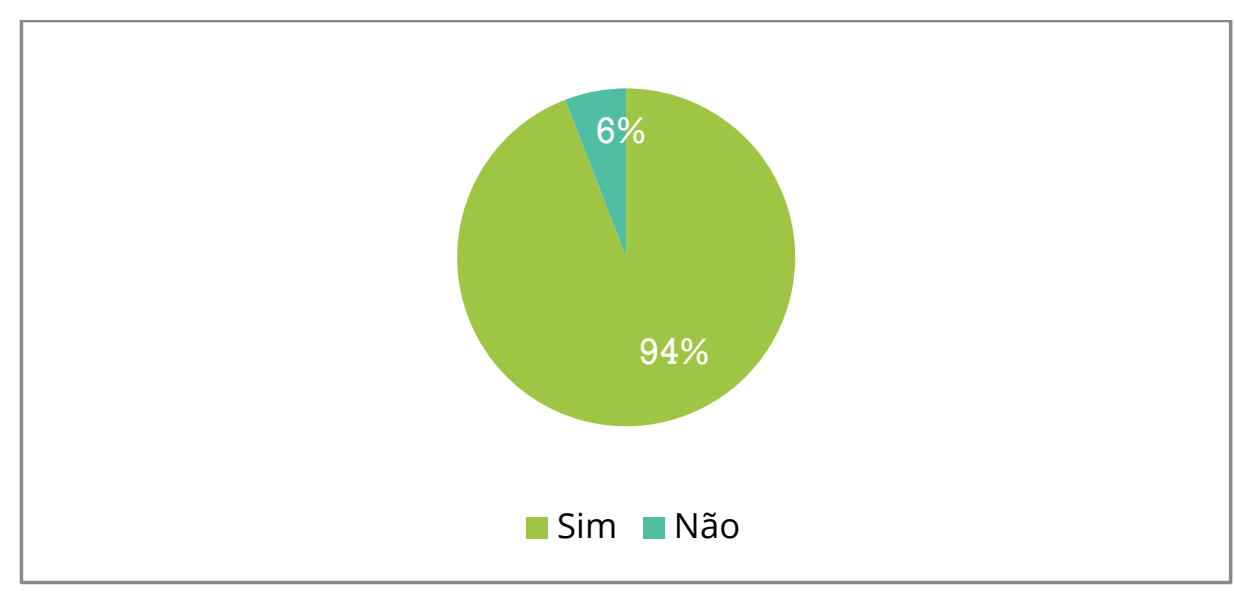

O gráfico 1 reafirma o fato do público-alvo não conhecer a identidade do IF Sudeste MG - Campus Rio Pomba. Obteve-se a confirmação da eficácia do produto educacional, bem como um indício de sua capacidade de sobressair em relação à imagem construída com base em informações extraoficiais. A imagem formada, quando existe, não corresponde exatamente à identidade da instituição e de sua proposta de formação. Por isso, o aplicativo apresentado aos estudantes 
demonstrou potencial na promoção de conhecimento. Não se pode desconsiderar que a ferramenta usufrui de certo nível de credibilidade, ao ter sido apresentada como um canal construído pela própria instituição - e, portanto, legítimo ${ }^{8}$.

Os entrevistados que confirmaram mudança da própria visão sobre o IF são unânimes em traduzir esta mudança em descobertas ou surpresas positivas (14 respostas): não conhecia nada, agora sei um pouco/ me ajudou a enxergar caminhos; por saber que no If tem vários cursos interessantes/ descobri um monte de coisa que escola oferece e que eu não sabia. Sobre as visões que não sofreram mudança, houve apenas uma justificativa manifesta: por mais que ele [o aplicativo] seja satisfatório eu ainda não sei o que eu quero ser, não sei se estou preparada para ter o dever e o comprometimento que vocês nos oferecem.

Gráfico 2 - Depois de usar o aplicativo, sua visão sobre o curso de Agropecuária mudou?

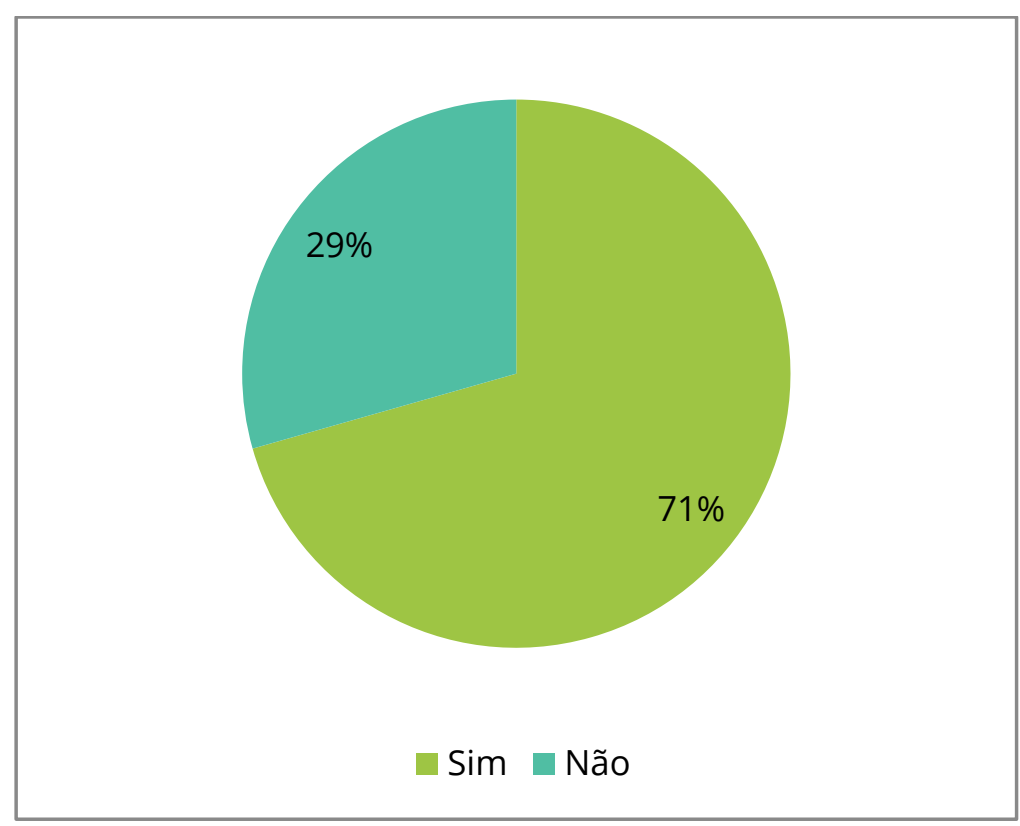

No Gráfico 2, a mudança de opinião repetiu-se como majoritária, embora $29 \%$ afirmou não ter mudado de opinião a respeito do curso. Nas 16 justificativas recebidas a respeito da mudança de visão sobre o curso, em 13 delas observou-se que a alteração significou exatamente uma reversão do desinteresse pela

\footnotetext{
${ }^{8}$ Embora tal processo não tenha sido relatado no presente artigo, a construção do aplicativo demandou um estudo documental, incluindo-se nele o Projeto Político Pedagógico do curso de Agropecuária (IF SUDESTE MG, 2018) e uma entrevista semiestruturada com alunos deste mesmo curso, no sentido de se compreender e delinear a identidade da instituição e da proposta formação em questão, antes de disseminá-las.
} 
Agropecuária. Ocorreu, portanto, fenômeno similar ao da questão anterior, porém as descobertas não foram especificadas, sendo mais recorrentes expressões como achei interessante, não conbecia e: cresceu a vontade de ir pro If. Apenas um dos respondentes especificou a descoberta com a frase: oportunidade de trabalhar em várias áreas. Já as três justificativas para a visão não ter sofrido mudança foram: não me interesso; não tenho interesse; e não é o que eu realmente quero.

Embora não seja o objetivo principal do aplicativo promover mudanças a respeito da visão de futuro para 94\% dos estudantes, trata-se de um importante indicativo na aferição do quanto ele é capaz de aumentar o comprometimento e prevenir a evasão escolar. Houve 13 entrevistados que explicaram o motivo da mudança. Eles expressaram motivação, como em: eu queria largar os estudos, agora quero agarrar as oportunidades; criação de perspectivas: lá na frente pode ser que eu amadureça um pouco mais e tento; e também reconhecimento quanto ao que os estudos podem proporcionar: posso ter mais coisas se eu estudar.

Os estudantes foram convidados a realizar a avaliação individual de cada segmento/ funcionalidade do aplicativo. De uma maneira geral, numa escala de 1 a 5 , predominaram notas a partir de 3 . As funções com maior número de notas baixas foram Depoimentos e Converse com um aluno (47\% dos estudantes classificaramnas com nota 1 ou 2). Sobre esta última, os comentários se resumiram a gostei. O mesmo ocorreu com Converse com um aluno e 6 coisas que você precisa saber.

Ao serem perguntados sobre os depoimentos, uma entrevistada revelou: para falar a verdade, dona, essa parte en pulei. O mesmo ocorreu com a função textual Mercado/ carreira (houve quem revelasse não tê-la explorado). Após esta percepção, os entrevistados foram questionados se o motivo seria o formato texto e, de fato, os alunos demonstraram aversão à leitura: se for muito grande, a gente desanima. Surgiu a sugestão do formato áudio, para a qual imediatamente surgiu nova ressalva: se tiver um áudio de mais de um minuto, eu não escuto também não. Em seguida, nova sugestão: resuminho, tópico, muito melhor.

As funções com maiores notas foram Rotina, Matérias e Agende uma visita. As duas últimas deste grupo destacaram-se pelo maior número de notas máximas em relação às demais funções: $35 \%$ dos respondentes as avaliaram como excelentes. 
Em uma das respostas aos questionários, a função Quiz foi criticada, parecendo destoar da expectativa por um Rolê no IF: achei que fosse tipo assim um rolê mesmo! Cheguei lá, um monte de pergunta. Entende-se aqui que o tour virtual seria capaz de atender à expectativa pelo rolê se a proposta tivesse sido concretizada segundo a ideia inicial ${ }^{9}$, de proporcionar a visão dos ambientes do Campus Rio Pomba em 360': seria muito chique, segundo uma das entrevistadas.

Perguntou-se se os adolescentes indicariam o aplicativo para um amigo que deseja ingressar no IF Sudeste MG, mas que ainda não tenha escolhido o curso. Todos eles responderam afirmativamente (100\%). Como possíveis melhorias, eles sugeriramm principalmente a ampliação do aplicativo, como foi dito. Esta se daria especialmente com o aumento da variedade de cursos. Há aqueles que complementaram o pedido, especificando: mais fotos e vídeos; vídeos dos alunos fazendo aulas práticas; vídeos dos professores explicando o curso. Um exemplo: quando instalei o aplicativo estava esperando por outra coisa como o aplicativo chama-se Rolê no If eu estava esperando algo como fotos do Ifet, mostrando detalhadamente como é os cursos do Ifet, explicando por meio de vídeos e tal. Outra entrevistada relatou: não foi uma coisa que me interessou porque não foi mais a fundo nisso. [Deveria] mostrar dentro mesmo... vídeo... a pessoa fazendo on-line.

Também foram registradas sugestões diferenciadas: introdução mais longa de todos os bimestres ${ }^{10}$; visitas com alunos fora do ifet (sic); possibilidade de uso do aplicativo sem internet; bate-papo com os professores. Houve, ainda quem respondesse: Tudo $e$ nada pois, não conseguir (sic) entender. Dois entrevistados pediram a disponibilização de provas e dois outros sugeriram a simplificação do aplicativo, algo que aparentemente destoa dos pedidos de detalhamento, de ir a fundo, traduzindo-se numa questão a ser investigada, caso o aplicativo venha a ser adotado institucionalmente.

\footnotetext{
${ }^{9}$ A alteração de ordem das funções foi realizada após a validação, conforme planejado. Além disso, a disponibilização de imagens para outros ambientes está prevista no projeto de ampliação aprovado pela Pró-Reitoria de Pesquisa e Inovação do IF Sudeste MG (já mencionado neste trabalho).

${ }^{10}$ Acredita-se que este relato obtido por meio do questionário on-line refira-se à função Matérias. A entrevistada manifesta curiosidade pelo conteúdo disciplinar em bimestres e não apenas ano a ano de curso, como o aplicativo mostra.
} 


\section{Considerações finais}

Apesar dos pontos de melhoria apontados nos questionários e da limitação ao curso de Agropecuária, o Rolê no IF, conclui-se que a inovação tecnológica foi capaz de incluir usuários ao universo institucional e à realidade do IF Sudeste MG - Campus Rio Pomba, promovendo conhecimento e até mudanças de perspectiva. Avaliou-se como pertinentes as críticas, contribuições e sugestões de melhoria, pois não representam modificações na essência da proposta, e que elas revelam a curiosidade por outros cursos, reforçando a aceitação do aplicativo como um canal de comunicação pública.

Contudo, a validação reforça um desafio já apontado na experiência de Bardagi (2007): a ausência de comportamento exploratório, expressa na recorrência de pedidos de mais fotos e, em menor escala, mais vídeos. O interesse pelas informações imagéticas (SABOIA; VIVA; VARGAS, 2013) mostra-se, de fato, intenso, em detrimento das demais funções, muito menos lembradas, até para serem criticadas. O hábito de visualizar longas sequências de fotos parece já ter sido adquirido, à maneira como se navega na rede social Instagram. Contudo, não se sabe até que ponto seria possível ampliar a funcionalidade do aplicativo, deixando de lado os recursos textuais uma vez que este não se resuma a uma pré-visualização de ambientes e do cotidiano da instituição, mas também se estenda aos aspectos curriculares e de carreira, de maneira a favorecer-se o engajamento a uma proposta de formação (EMI), juntamente com seus desafios, e à perspectiva de um futuro profissional com o qual o estudante se identifica. Pois ao apostar nesta carreira e nesta proposta de formação é que seriam minimizadas as chances de o estudante evadir-se ao longo da trajetória (TINTO, 1975; BARDAGI, 2007; DORE; LUSCHER, 2011).

Assim, neste estudo foram apontadas possibilidades para o IF Sudeste MG trabalhar a comunicação pública em prol do conhecimento de identidades e da inclusão antecipada de adolescentes ao universo do EMI e de seus cursos, no sentido de ampliar as chances de permanência e prevenir-se a evasão escolar pelo 
combate à sua principal causa. Mensurar os resultados do aplicativo sobre o fenômeno da evasão não é uma tarefa simples, pois como se viu, a evasão é um problema complexo e seus índices sofrem influência de diversos fatores (DORE; LUSCHER, 2011). Todavia, o engajamento dos usuários e o número de downloads, bem como pesquisas com ingressantes que utilizaram o aplicativo, são indicadores possíveis para se aferir o quão eficaz estaria sendo a tecnologia, considerando o objetivo a que se propõe.

Ademais, não se pode prescindir de uma (re)avaliação periódica que considere possíveis mudanças de hábitos e de mídias adotadas no cotidiano juvenil - um desafio para instituições escolares que se limitam aos próprios muros, desconsiderando a realidade da sociedade de onde vêm seus alunos e impondo a exigência de uma adequação ou adaptação prepotente. De acordo com Brenner e Carrano (2014),

o desafio dialógico para educadores e formuladores de políticas educacionais é exercitar a abertura necessária para a incorporação dessas vozes juvenis na arena pública de tomada de decisões relacionadas com a melhoria da escola (p. 1237).

Ficam aqui diretrizes para a ampliação, aperfeiçoamento e disponibilização do aplicativo institucionalmente, na expectativa de um estudo conseguinte, por meio do qual se conheça melhor a eficácia da presente proposta. Tratando-se de uma experiência inédita, sugere-se ainda sua ampliação como canal inovador de comunicação pertinente a todo o IF Sudeste MG ou mesmo para toda a Rede Federal, respeitados os contextos do EMI de cada instituição.

\section{Referências}

ALENCAR, G.; PESSOA, M. S.; SANTOS, A. K. F. S.; CARVALHO, S.; LIMA, H. A. B. Whatsapp como ferramenta de apoio ao ensino. In: Latin American Conference of Learning Objects (LACLO), 2015. Maceió. Anais... 2015. p. 787-795.

BARDAGI, M. P. Evasão e comportamento vocacional de universitários: estudo sobre desenvolvimento de carreira na graduação. 242 f. Tese (Pós-Graduação em Psicologia do Desenvolvimento) Universidade Federal do Rio Grande do Sul, Porto Alegre, 2007.

BARDIN, L. Análise de conteúdo. Trad. Luís Antero Reto e Augusto Pinheiro. São Paulo: Edições 70, 2011. 
BRANDÃO, E. Conceito de comunicação pública. In: DUARTE, J. (Org.). Comunicação pública: estado, mercado, sociedade e interesse público. 2. ed. São Paulo: Atlas, 2009.

BRANDÃO, E. CARVALHO, B. Imagem corporativa: marketing da ilusão. In: DUARTE, J. Assessoria de imprensa e relacionamento com a mídia. São Paulo: Atlas, 2009. p. 189-205.

BRASIL. Constituição da República Federativa do Brasil. Brasília, DF: Senado Federal: Centro Gráfico, 1988. 292 p.

BRASIL. Lei no 11.892, de 29 de dezembro de 2008. Institui a Rede Federal de Educação Profissional, Científica e Tecnológica, cria os Institutos Federais de Educação, Ciência e Tecnologia. Diário Oficial da República Federativa do Brasil, Brasília, DF, 30 dez. 2008. Disponível em: <http://www.planalto.gov.br/ccivil_03/_ato2007-2010/2008/lei/111892.htm> Acesso em: 22 nov. 2017.

BRASIL. Casa civil. Lei no 12.852, de 5 de agosto de 2013. Institui o Estatuto da Juventude e dispõe sobre os direitos dos jovens, os princípios e diretrizes das políticas públicas de juventude e o Sistema Nacional de Juventude - SINAJUVE.

BRASIL. Lei $\mathrm{n}^{\mathrm{a}}$ 12.527, de 18 de novembro de 2011. Dispõe sobre o acesso a informações públicas. Disponível em: < http://www.planalto.gov.br/ccivil_03/_ato2011-2014/2011/lei/112527.htm>. Acesso em: 30 mar. 2019.

BRENNER, A. K. CARRANO, P. C. R. Os sentidos da presença dos jovens no Ensino Médio: representações da escola em três filmes de estudantes. Educ. Soc., Campinas, v. 35, n. 129, p. 1223-1240, out./dez., 2014.

CRESCE número de crianças e adolescentes que buscam notícias na Internet, aponta Cetic.br. Cetic.br, 18 de Set. de 2018. Disponível em: $<$ https://www.cetic.br/noticia/cresce-numero-de-criancas-e-adolescentes-que-buscamnoticias-na-internet-aponta-cetic-br/> Acesso em: 04 abr. de 2019.

DORE, R.; LUSCHER, A. Z. Permanência e evasão na educação técnica de nível médio em Minas Gerais. Cad. Pesqui., São Paulo , v. 41, n. 144, p. 770-789, dec. 2011. http://dx.doi.org/10.1590/S0100-15742011000300007

FRIGOTTO, G., CIAVATTA, M. (orgs.). Ensino médio: ciência, cultura e trabalho. Brasília, MEC/SEMTEC, 2004. 338p.

IFS DIGITAL. IFS Digital, 2018. Aplicativo para estudantes do Instituto Federal do Sergipe. Disponível em: <https://play.google.com/store/apps/details?id=br.edu.ifs.ifsdigital\&hl=pt_BR>. Acesso em: 04 abr. 2019.

IF SUDESTE MG. Plano Estratégico para a Permanência e Êxito dos Estudantes do IF Sudeste MG. Juiz de Fora, MG, 2016. Disponível em: < https://www.ifsudestemg.edu.br/sites/ default/files/PLANO $\% 20$ PERMANENCIA $\% 20$ E $\% 20$ EXITO $\% 20 \% 20-\% 20$ final_1_0.pdf>. Acesso em: 29 nov. 2017

IF SUDESTE MG. Plano de Desenvolvimento Institucional do IF Sudeste MG. Juiz de Fora, MG, 2014. Disponível em: <https://www.ifsudestemg.edu.br/documentosinstitucionais/pdi/pdi-2014-2019-versoes> 
IF SUDESTE MG. Projeto Pedagógico de Curso: Curso Técnico Integrado em Agropecuária. Rio Pomba: 2018. Disponível em:

<https://www.riopomba.ifsudestemg.edu.br/portal/sites/default/files/arq_paginas/PPC \%20Agropecuaria\%20Integrado\%202018.pdf> Acesso em: 08 maio 2019.

INTERVOZES, COLETIVO BRASIL DE COMUNICAÇÃO SOCIAL. Relatório da Pesquisa Direito à Comunicação no Brasil: Base constitucional e legal, implementação, o papel dos diferentes atores e tendências atuais e futuras. Terceira Versão. Junho de 2005. Disponível em: < http://livros01.livrosgratis.com.br/oi000011.pdf>. Acesso em: 22 nov 2018.

LIMA, N. T. Juventude e Ensino Médio: de costas para o futuro? In: FRIGOTTO, G. \& CIAVATTA, M. (orgs.). Ensino médio: ciência, cultura e trabalho. Brasília: MEC/SEMTEC, 2004. 338p.

LOPES, B. (Org.). Gestão em Comunicação Empresarial: teoria e técnica. Juiz de Fora: Produtora Multimeios, 2007.

LÓPEZ, J. C. J. Proposta geral da comunicação pública. In: DUARTE, J. Comunicação Pública: Estado, sociedade e interesse público. 2. ed. São Paulo: Atlas, 2012.

MINISTÉRIO DA EDUCAÇÃO. Plataforma Nilo Peçanha, 2019. Ambiente virtual de coleta, validação e disseminação das estatísticas oficiais da Rede Federal de Educação Profissional e Tecnológica. Disponível em: <http://plataformanilopecanha.mec.gov.br/>. Acesso em: 07 abr. 2019.

RAMOS, M. N. Concepção do ensino médio integrado. In: Seminário sobre Ensino Médio, 2008. Secretaria de Educação do Pará. 08-09 maio, 2008

SABOIA, J.; VIVA, M. A. A.; VARGAS, P. L. O uso dos dispositivos móveis no processo de ensino e aprendizagem no meio virtual. Revista Cesuca Virtual: Conbecimento sem fronteiras, v. 1, n. 1, jul. 2013. Disponível em: $<$ http://ojs.cesuca.edu.br/index.php/cesucavirtual/article/view/424>. Acesso em: 27 nov. 2018.

SILVA, A. M. Facebook como ferramenta de interação no ensino de informática. 2016. 110 f. Dissertação (Mestrado em Educação) - Universidade Federal de Rondônia, Porto Velho, 2016a.

SILVA, A. M. Facebook como ferramenta de interação no ensino de informática. Revista De Estudos E Pesquisas Sobre Ensino Tecnológico (EDUCITEC), Manaus, v. 4, n. 8, p. 23-29, nov/2018. Doi: https://doi.org/10.31417/educitec.v4i08.350

SILVA, K. J. A prática do ensino superior na identidade discente e docente: como a tecnologia educacional pode reduzir a evasão escolar. Qualis Sumaré - Revista Acadêmica Eletrônica, v. 13 e 14, jan./dez. 2016b. 
SILVA, M. R.; PELISSARI, L. B.; STEIMBACH, A. A. Juventude, escola e trabalho: permanência e abandono na educação profissional técnica de nível médio. Educ. Pesqui., São Paulo, v. 39, n. 2, p. 403-417, abr./jun. 2013.

TINTO, V. Dropout from higher education: a theoretical synthesis of recent research. Teachers College Columbia University: Columbia, 1975.

RECEBIDO: $14 / 06 / 2019$ APROVADO: $12 / 11 / 2019$

RECEIVED: 06/14/2019 APPROVED: $11 / 12 / 2019$

RECIBIDO: $14 / 06 / 2019$ APROBADO: $12 / 11 / 2019$ 